\title{
DARI PIAGAM MENJADI RELIK: \\ Pergeseran Pemaknaan Prasasti yang tersimpan di dalam Pura-pura di Kawasan Danau Batur, Bali ${ }^{1}$
}

\author{
Tjahjono Prasodjo ${ }^{2}$ \\ Email: tprasodjo@gmail.com
}

\begin{abstract}
ABSTRAK
Di desa-desa sekitar Danau Batur, Kabupaten Bangli, Propinsi Bali banyak dijumpai prasasti yang disimpan di pura-pura desa. Prasastiprasasti tersebut telah mengalami tranformasi pemaknaan yang sudah sangat berbeda dengan makna dan fungsi aslinya. Artikel ini berupaya untuk mengungkapkan proses perubahan pemaknaan prasasti di pura-pura di sekitar Danau Batur. Dari hasil observasi di lapangan dan studi pustaka diketahui bahwa masih terdapat prasasti-prasasti kuno yang disimpan setidaknya di lima pura desa di sekitar Danau Batur. Prasasti-prasasti tersebut memuat data historis yang sangat bermakna untuk merekonstruksikan sejarah lokal maupun sejarah Bali secara keseluruhan. Namun, saat ini peneliti sejarah dan arkeologi sangat sulit untuk mengakses data tersebut. Di dalam masyarakat telah terjadi perubahan pemaknaan prasasti, dari makna piagam bergeser menjadi relik yang sangat dikeramatkan. Perubahan tersebut harus disikapi secara bijaksana oleh para peneliti dan masyarakat sebagai pemilik dan "penjaga" prasastiprasasti tersebut. Pergeseran pemaknaan tersebut memang merupakan suatu proses budaya yang wajar. Namun, diharapkan data historis yang terkandung dalam prasasti dapat diakses dan dimanfaatkan secara akademis untuk mengungkapkan sejarah dan jatidiri masyarakat di wilayah tersebut.
\end{abstract}

Kata kunci: prasasti Bali kuno, terunyan, pergeseran pemaknaan.

\section{ABSTRACT}

Villages around Lake Batur, Bangli District, Bali Province have many inscriptions kept in their puras. The inscriptions have been experiencing a transformation of significance which is very different from the original meaning and function of an inscription. This article is meant to reveal the process of transformation of the inscriptions kept in the temples in the

\footnotetext{
1 Artikel ini merupakan hasil penelitian yang didanai oleh Program Beastudi Kajian Antarbudaya/ Antarregional, Pusat Studi Asia Pasifik, Universitas Gadjah Mada pada tahun 2005/2006.

2 Staf Pengajar Jurusan Arkeologi, Fakultas IImu Budaya, Universitas Gadjah Mada.
} 
vicinity of Lake Batur. Based on the results of field observations and literature studies have been known that there are ancient inscriptions kept in at least five temples in the villages around Lake Batur. The inscriptions contain a very significant historical and socio-cultural data about local history. However, historians and archaeologist are very difficult to access the data. There has been a change of how the community sees the significance of an inscription, shifting from a charter to a very sacred relic. Such changes must be addressed wisely by the researchers and the community as the owner and "keeper" of such inscriptions. The shift of meaning is indeed as a naturally cultural process. It is, however, I expect that the historical data contained in the inscription can still be accessed and used academically to reconstruct the history and community identity in the region.

Keywords: Ancient Balinese inscriptions, terunyan, shift in meaning

\section{PENDAHULUAN}

\section{Yumu Pakatahu}

Frasa di atas merupakan kata-kata pembuka dalam banyak prasasti Bali, yang berarti "ketahuilah oleh kamu sekalian". Kata-kata tersebut menyiratkan bahwa hal yang sudah ditetapkan dalam prasasti haruslah diketahui oleh semua orang, agar segala ketetapan yang telah dikeluarkan dapat dilaksanakan dengan sebaik-baiknya.

Namun, dalam kenyataannya pada masa kini di Bali telah terjadi pergeseran dalam pemaknaan prasasti. Pada masyarakat Bali telah terjadi sakralisasi prasasti. Pada masa lalu prasasti dipandang sebagai sebuah piagam penetapan yang memang ditujukan untuk dapat dibaca oleh semua orang, tetapi pada masa kini prasasti dimaknai sebagi relik keagamaan yang sangat disakralkan. Artikel ini akan membahas perubahan pemaknaan tersebut di daerah atau kawasan Danau Batur, Kintamani, Bali. Pada bagian awal artikel akan dideskripsikan prasasti-prasati yang ditemukan di sekitar kawasan penelitian. Selanjutnya, bagian-bagian berikutnya adalah analisis yang dilakukan oleh peneliti terhadap perubahan pemaknaan tersebut. Analisis didasarkan atas studi literatur dan penelitian lapangan yang dilakukan di kawasan Danau Batur pada tahun 2005 dan 2006. Pada bagian akhir akan disajikan refleksi terhadap perubahan pemaknaan prasasti di kawasan Danau Batur.

\section{PRASASTI DI DALAM PURA DI KAWASAN DANAU BATUR}

Boechari (1977) mendefinisikan prasasti sebagai "sumber-sumber sejarah dari masa lampau yang tertulis di atas batu dan logam". Bakker (t.t.) menyatakan bahwa prasasti merupakan "suatu putusan resmi, tertulis di 
atas batu \& logam, dirumuskan menurut kaidah-kaidah tertentu, berisikan anugerah dan hak, yang dikaruniakan dengan beberapa upacara". Adapun Kamus Arkeologi (Ayatrohaedi, 1981) menjabarkan prasasti dengan "pertulisan kuno yang biasanya dipahatkan atau digoreskan di atas batu, logam, atau daun tal (lontar)". Dengan demikian pada dasarnya prasasti adalah piagam penetapan yang dikeluarkan oleh penguasa mengenai berbagai hal, antara lain status wilayah, pajak, utang-piutang, sengketa tanah, dan penetapan perdikan (Prasodjo, 1998). Prasasti yang menjadi bahasan dalam tulisan ini adalah prasasti atau pertulisan yang berasal dari masa Bali Kuno atau Bali Klasik.

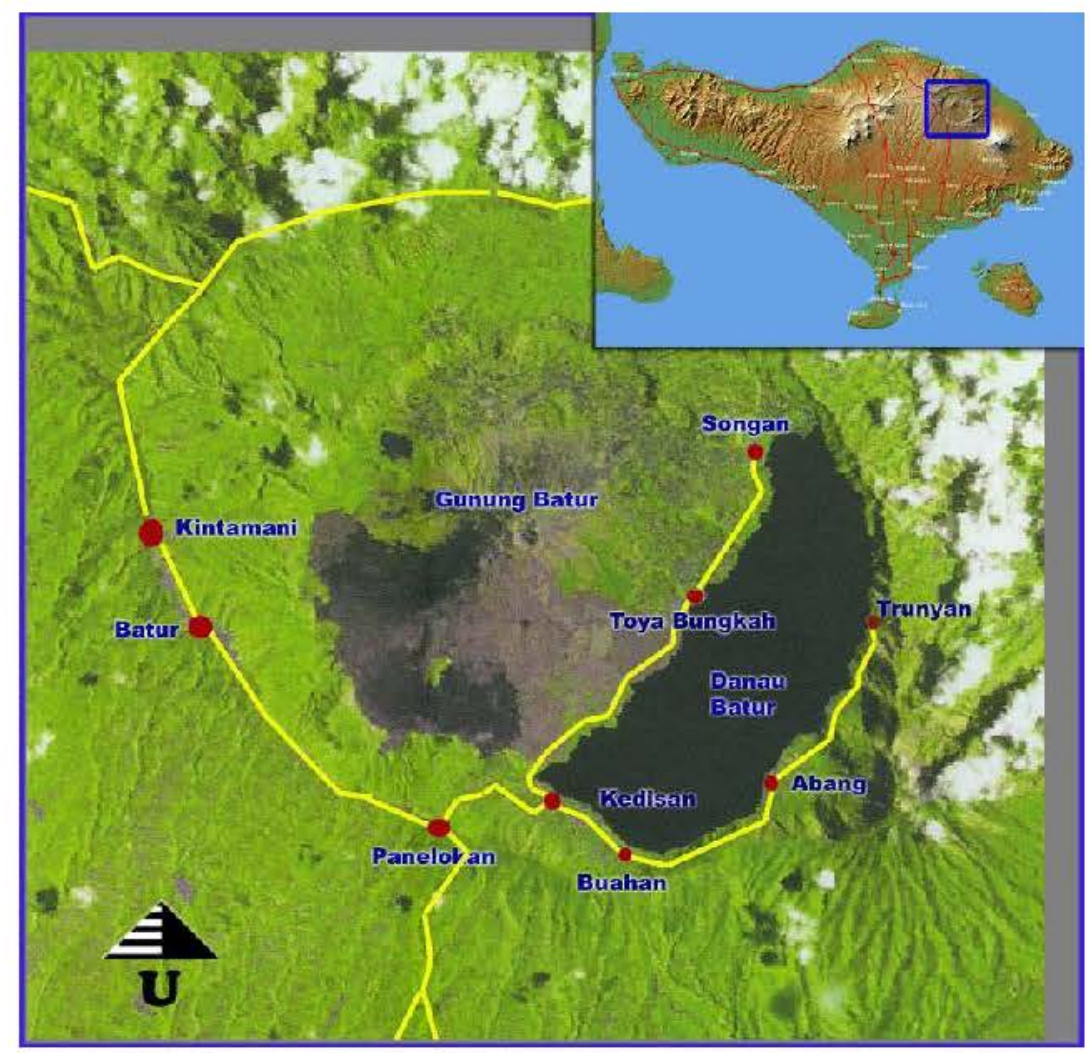

Peta Kawasan Danan Batur

[peta Bali (inset) oleh J. Susetyo Edy Y.]

Penelitian prasasti di Pulau Bali sebenarnya sudah dimulai pada tahun 1885 dengan diterbitkannya sebuah artikel yang berjudul "Transcripties van vier oorkonden in koper, gevonden op het eiland Bali" dalam T.B.G. No. 30. Keempat prasasti yang dipublikasikan tersebut merupakan prasasti yang berasal dari Sawan, Sangsit, dan Klandis (Kartoatmodjo, et al. 1977: 3). Penelitian prasasti yang berasal dari sekitar Danau Batur baru muncul 25 tahun kemudian, setelah P.V. van Stein 
Callenfels menerbitkan bukunya berjudul Epigraphia Balica pada tahun 1926 yang memuat 25 buah transkripsi prasasti-prasasti Bali.

Beberapa di antaranya merupakan prasasti-prasasti yang berasal dari kawasan Danau Batur, yaitu: Prasasti Truñan A, Truñan B, Truñan C, Buwahan A, Buwahan B, Buwahan C, Buwahan D, Buwahan E, Pura Kehen A, Pura Kehen B, dan Pura kehen C. Setelah itu, tahun berikutnya dilakukan pemotretan prasasti-prasasti di daerah Bangli, Kintamani, termasuk prasasti di sekitar Danau Batur oleh seorang juru foto Cina atas perintah Residen Caron. Pada tahun 1954 beberapa prasasti dari sekitar Danau Batur dikaji kembali dan diterbitkan kembali oleh Goris dalam bukunya yang berjudul Prasasti Bali I dan Prasasti Bali II. Dalam kedua buku tersebut Goris selain menerbitkan transkrip prasasti, juga menterjemahkannya ke dalam bahasa Belanda, disertai dengan ringkasan dalam bahasa Inggris dan Indonesia.

Prasasti-prasasti di Bali masih terus diteliti, baik oleh peneliti asing maupun peneliti Indonesia, tetapi penelitian tentang prasasti sekitar Danau Batur tidak begitu banyak dilakukan. Penelitian prasasti Danau Batur yang dapat diketahui adalah prasasti dari Desa Terunyan yang dilakukan sebanyak dua kali. Pada bulan Nopember di tahun 1984 sebuah tim peneliti datang ke Desa Terunyan untuk meneliti prasasti-prasasti yang tersimpan di Pura Desa Terunyan. Tim peneliti menemukan beberapa prasasti telah mengalami kerusakan atau keausan sehingga harus dilakukan tindakan konservasi (Budiastra dan Wardha 1990: 1-2). Penelitian yang kedua dilakukan oleh peneliti dari Museum Bali yakni Putu Budiastra dan Wayan Wardha (/bid.), dan hasilnya diterbitkan dalam sebuah tulisan yang berjudul "Prasasti Desa Trunyan Kintamani". Di dalam tulisan ini termuat transkripsi, terjemahan, dan sedikit analisis mengenai keempat kelompok prasasti dari Desa Terunyan.

Berikut ini paparan prasasti-prasasti yang disimpan (atau diduga disimpan) di beberapa pura di kawasan Danau Batur.

\section{Pura Desa Terunyan}

Prasasti Turuñan terdiri atas empat kelompok prasasti yang kesemuanya berjumlah sebelas lempeng tembaga. Keseluruhan prasasti saat ini disimpan di sebuah pelinggih berbentuk meru tumpang lima yang disebut Pelinggih Ratu Sakti Meduwe Raja (Budiastra dan Wardha 1990: 1).

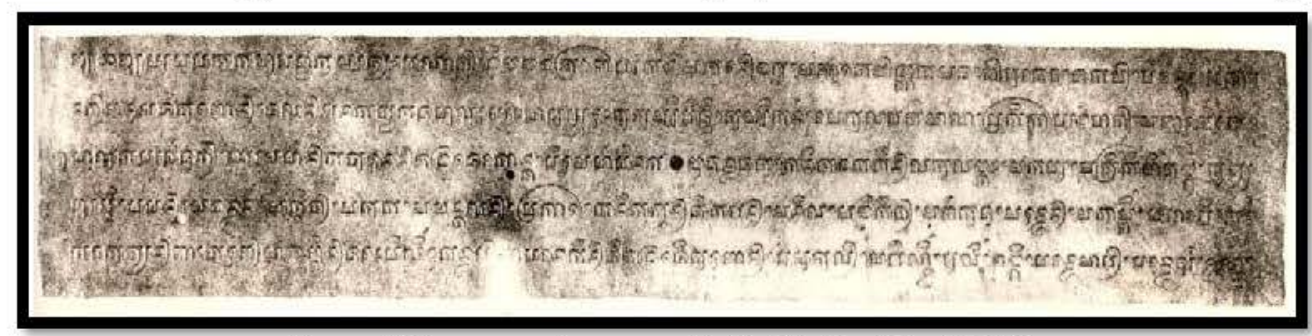

Prasasti Turufisn, lexpeng B 1b (Callenfels, 1925) 
Kelompok prasasti yang pertama berjumlah empat lempeng tembaga berangka tahun 833 Śaka $(911 \mathrm{M}$.), serta berhuruf dan berbahasa Bali Kuno. Isinya tentang pemberian ijin kepada desa Turuñan untuk mendirikan bangunan suci bagi Bhațāra Da Tonta. Penduduk desa oleh karenanya dibebaskan dari beberapa jenis pajak, tetapi masih tetap harus menyerahkan sumbangan bagi kuil tersebut. Disebutkan pula beberapa pajak yang harus dibayarkan pada bulan tertentu, dan kewajiban untuk menjamu utusan raja yang datang ke kuil tersebut. Dikemukakan juga tentang upacara di kuil yang disebut dengan guha mangurug jalalingga dan di sang hyang Turuñan. Kemudian dituliskan juga mengenai hak waris, pajak-pajak di beberapa desa, dan batas-batas desa yang telah ditetapkan (Budiastra dan Wardha 1977; Goris 1954: 183; Sumadio, ed. 1990: 286).

Kelompok prasasti Terunyan yang kedua berangka tahun sama yaitu $833 S$ (911 M.) dan diawali dengan kalimat-kalimat yang mirip dengan kelompok pertama. Namun, selanjutnya menjelaskan tentang orang-orang Air Rawang yang tinggal di wilayah Desa Turuñan yang berada di sebelah timur balongan (teluk) danau. Disebutkan bahwa para bulan Bhadrawada para sahayan padang dari desa Air Rawang diwajibkan untuk melakukan upacara penghormatan kepada Bhațāra Da Tonta dengan cara: memandikan dengan air danau, memberi bedak kuning, dan menghiasi dengan cincin dan gelang permata. Pada akhir prasasti terdapat śapatha (kutukan) bagi yang melanggar ketetapan tersebut (Budiastra dan Wardha 1977; Goris 1954; Sumadio, ed. 1990).

Kelompok yang ketiga berangka tahun 971 Śaka (1019 M.) berisi tentang keputusan raja membagi tanah di Turuñan dan menetapkan batasbatasnya. Kelompok prasasti yang terakhir juga berangka tahun 971 Śaka (1019 M.) berisi tentang permohonan penduduk desa Turuñan kepada raja untuk mengukuhkan kembali isi prasasti yang terdahulu untuk dituliskan kembali ke atas prasasti tembaga, karena tulisan pada prasasti sebelumnya telah rusak. Ketetapan ini diputuskan oleh raja di hadapan para tanda rakryan (pejabat tinggi, setingkat menteri) dalam sebuah Dewan Persidangan (Budiastra dan Wardha 1990: 17-20).

\section{Pura Tulukbiyu, Batur}

Prasasti Tulukbiyu pada saat ini tersimpan di dalam Meru tumpang tiga di Pura Tulukbiyu atau disebut juga Pura Batur Kanginan yang terletak di Desa Batur, Kecamatan Kintamani, Kabupaten Bangli (Kartoatmodjo, et al. 1977: 11-12). 


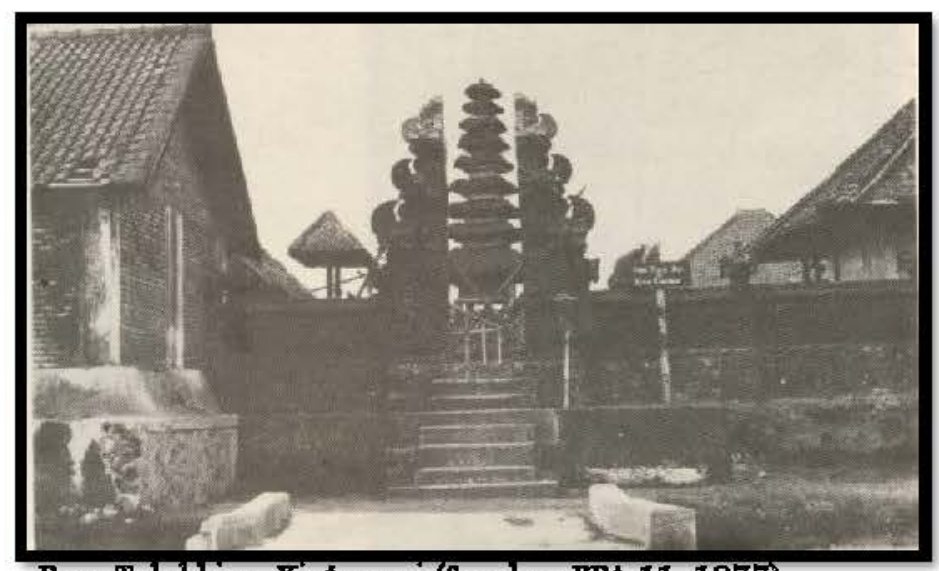

Pura Tulukbyy, Kmtamari (Sumber: BPA 11, 1977)

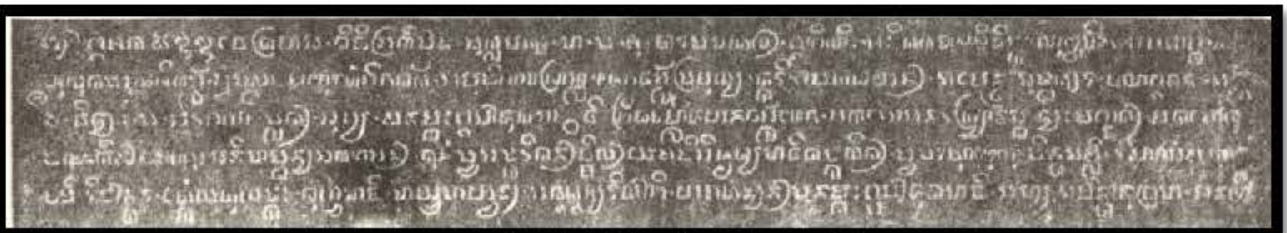

Prasasti Tuhulfoiyu (Goris, 1954)

Huruf dan bahasa yang dipergunakan prasasti Tulukbiyu adalah Jawa Kuno. Prasasti-prasasti tersebut dapat dikelompokkan atas tiga kelompok, yaitu: Tulukbiyu A (Batur Pura Abang A) yang berangka tahun 933 Śaka, Tulukbiyu B (Batur Pura Abang B) berangka tahun 1103 Śaka, dan Tulukbiyu C (Batur Pura Abang C) berangka tahun 1306 Śaka (Bandingkan: Suarbawa 2005:122).

Prasasti Tulukbiyu A (Batur Pura Abang A) berisi keberatan penduduk Desa Air Hawang karena mereka kekurangan lokasi rumah. Oleh karena itu, Raja membentuk sebuah komisi untuk menyelidiki hal tersebut. Komisi tersebut menemukan bahwa keberatan penduduk desa tersebut memang benar. Pajak-pajak kemudian ditetapkan kembali. Di samping itu, juga ditetapkan mengenai masalah pemeliharaan kuda. Penduduk desa juga diharuskan untuk memberi sumbangan ke kuil di desa Turuñan.

Menurut beberapa informasi, baik dari penduduk sekitar Danau Batur maupun dari kalangan peneliti (Suarbhawa 2005: 122) prasastiprasasti yang disimpan di pura di Desa Batur tersebut sebenarnya berasal dari desa di tepi Danau Batur. Kemungkinan dari Pura Telukbiyu yang terdahulu yang terletak di dekat Gunung Abang.

\section{Pura Desa Songan}

Prasasti di Pura Desa Songan masih belum banyak diketahui keberadaannya. Kemungkinan bahwa prasasti tersebut disimpan di salah satu pura di Songan yang cukup besar, yakni Pura Ulundanu, juga belum

diketahui secara tegas. Ketika wawancara dilakukan dengan Bapak Jro 
Mangku Ulundanu didapat informasi bahwa di pura tersebut terdapat beberapa prasasti, tetapi belum didapat keterangan secara pasti apakah berupa prasasti dari tembaga atau lontar (biasa disebut pretasti oleh masyarakat Bali). Nampaknya masih terdapat kesulitan untuk mengungkapkan keberadaan prasasti di desa Songan, seperti juga pernah dialami oleh peneliti epigrafi di masa lalu, yaitu Putu Budiastra dan Soekarto Kartoatmodjo. Putu Budiastra (1977: 14) menuliskan pengalamannya:

"Pengalaman lainnya yang kami hadapi yaitu pada waktu kami mendatangi penduduk desa Songan yang menyimpan prasasti dan memohon agar diperkenankan melakukan penelitian, penduduk desa merelakan prasastinya diteliti tetapi dengan persyaratan yang memusingkan kami. Penelitian dapat dilaksanakan asal rombongan peneliti sanggup menanggung beban seluruh biaya upacaranya termasuk enam ekor kerbau bertanduk emas yang harus diserahkan kepada desa."

Soekarto Kartoatmodjo menuliskan pengalamannya dalam penelitian prasasti di Bali pada laporannya sebagai berikut:

"Menurut kabar sebuah prasasti yang tersimpan dalam sebuah gua di daerah Songan di tepi danau Batur, hanya dapat dibaca apabila diadakan upacara besar-besaran dengan menyembelih kerbau 9 ekor dan upacara-upacara lainnya yang cukup besar."

\section{Pura Desa Kedisan}

Kasus di Desa Kedisan hampir sama dengan yang dijumpai pada kasus di Songan. Menurut salah satu staf peneliti Balai Arkeologi Denpasar, I Gusti Made Suarbhawa, penelitian prasasti yang pernah dilakukan di Kedisan menemui kendala dalam perijinan pembacaan prasasti. Ketika peneliti bermaksud memohon ijin untuk membaca prasasti di pura Kedisan diberikan syarat yang cukup memberatkan bagi tim peneliti. Disebutkan bahwa untuk dapat membaca prasasti harus diadakan upacara ritual disertai dengan persembahan kerbau dan perhiasan emas.

\section{Pura Desa Buahan}

Prasasti Buwahan terdiri dari lima kelompok prasasti, yaitu Buwahan A (916 Śaka), Buwahan B (947 Śaka), Buwahan C (1068 Śaka), Buwahan D (1103 Śaka), dan Buwahan E (1103 Śaka) (van Stein Callenfels 1926: 2745). Callenfels menyatakan bahwa prasasti ini berasal dari Desa Buahan. Menurut dugaan penulis prasasti ini masih berada di pura Desa Buahan, tetapi perlu konfirmasi lebih jauh lagi, karena setelah bencana gunung berapi pada tahun 1963 banyak terjadi perpindahan lokasi pura maupun prasastinya. 
Hasil ringkasan pembacaan Goris (1954: 188) terhadap prasasti Buwahan $A$ adalah sebagai berikut:

"Pada djaman dahulu Bwahan itu, menurut prasasti seorang radja jang telah ditjandikan di Nusa Dwa, dibawah perintah desa Kọisan. Sekarang orang Bwahan mohon supaja dimerdekakan dari desa Kọisan. Padjak ${ }^{2}$ ja jang dibajar oleh Bwahan ditetapkan. Mereka harus membajar sumbangan untuk kuil Hyang Api dan membangun pesanggrahan untuk orang jang berdjalan. Batasnja ditetapkan.

Perihal warisan diurus. Tersebut pula undang ${ }^{2}$ untuk orang ${ }^{2}$ jang djahat. Orang Bwahan harus menolong pekerdjaan di kuta, Cading dan didesa Bharu. Pada tiap ${ }^{2}$ bulan Māgha harus menjumbangkan juran sematjam ikan telaga (dèlěg, ñalian dsb). Desa tersebut harus pula menolong memperbaiki kuil (umah sanghyang) di Turuñan."

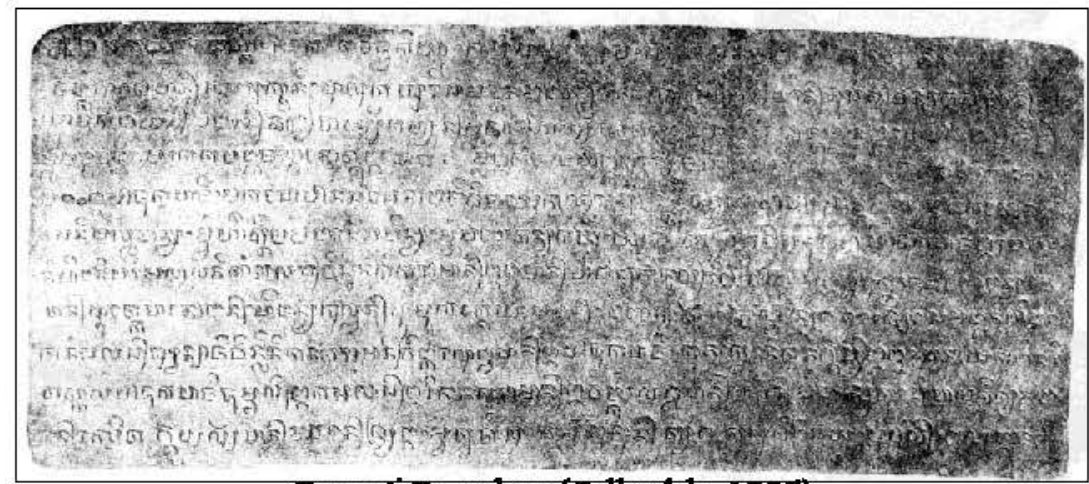

Prasasti Buwahan (Callenfels, 1925)

\section{DATA HISTORIS SEBAGA “HARTA KARUN” YANG DIPENDAM}

Pada tahun $1941 \mathrm{R}$. Goris menuliskan sebuah artikel yang berjudul Enkele Historische en Sociologische Gegevens uit de Balische Oorkonden yang telah diterjemahkan menjadi sebuah buku kecil dengan judul Beberapa Data Sejarah dan Sosiologi dari Piagam-piagam Bali. Dalam buku tersebut Goris (1974: 9) secara eksplisit menegaskan bahwa dalam beberapa tahun sebelum tahun 1941 tidak ada penelitian dan tulisan tentang arkeologi dan epigrafi (prasasti) Bali. Lebih lanjut lagi Goris memperkirakan bahwa dalam beberapa tahun di depannya akan terjadi hal yang sama. Akan tetapi,kekuatiran Goris tersebut tidak sepenuhnya benar, karena beberapa tahun berikutnya terdapat beberapa penerbitan tentang arkeologi dan epigrafi Bali, bahkan dia sendiri menulis beberapa buku. Namun, apabila dibandingkan dengan penerbitan tentang arkeologi dan epigrafi Jawa, Bali memang dari segi kuantitas lebih sedikit.

Salah satu penyebabnya adalah sedikitnya prasasti-prasasti baru (ditemukan atau dibaca) yang muncul ke permukaan. Ketidakmunculan 
prasasti-prasasti Bali dapat diibaratkan seperti "harta karun" yang sengaja "dipendam" oleh pemiliknya. Banyak prasasti yang masih "dipendam" di pura-pura Bali karena memang sengaja tidak boleh dibaca oleh peneliti maupun masyarakat awam. Padahal prasasti-prasasti tersebut tentunya mengandung data historis yang sangat kaya.

Prasasti-prasasti yang berasal dari sekitar Danau Batur yang sudah berhasil dibaca dan diteliti secara epigrafis dapat menjadi contoh kekayaan data historis yang dimiliki prasasti-prasasti Bali. Kekayaan tersebut akan berlimpah seandainya beberapa prasasti di sekitar Danau Batur yang masih disimpan di pura-pura diperbolehkan untuk dibaca dan diteliti. Berikut ini uraian tentang potensi data historis yang dapat digali dari prasastiprasasti di sekitar Danau Batur yang sudah berhasil dibaca.

Prasasti Terunyan yang berangka tahun 833 Śaka memberi data yang lebih tegas lagi tentang keberadaan masyarakat Terunyan sendiri. Pemberitaan dalam prasasti tersebut menjelaskan tentang adanya pembangunan kuil untuk Bhațāra Da Tonta. Tokoh ini diwujudkan sebagai sebuah arca megalitik setinggi empat meter. Sampao saat ini Arca Bhatāara Da Tonta masih berada dan dipuja di pura Desa Terunyan. Data historis tersebut menguatkan pendapat bahwa masyarakat Terunyan sudah tua dan masih sangat kental dengan tradisi masa prasejarah (megalitik). Penelitipeneliti antropologi (Danandjaja 1989; Reuter 2002; Otto 1994) memang menggolongkan masyarakat kawasan Danau Batur ini sebagai masyarakat Bali Mula atau Bali Aga yang sering didefinisikan sebagai masyarakat asli Bali. Bahkan, mereka pun masih melaksanakan ritual upacara pembersihan arca Bhatāa Da Tonta seperti yang diperintahkan di dalam prasasti Terunyan B. Pada setiap tahun dilakukan pemandian arca dengan air danau dan arca tersebut juga dibedaki, hanya saat ini bedak yang dipergunakan berwarna putih berasal dari bahan batuan mineral yang ditemukan di sekitar desa Terunyan, bukan lagi berwarna kuning.

Selain itu, data historis yang dikandung oleh prasasti-prasasti Danau Batur cukup beragam, mulai dari masalah keagamaan sampai masalah kehidupan keseharian masyarakat Danau Batur di masa lalunya. Prasasti Buwahan $\mathrm{C}$ memberikan gambaran tentang keagaaman di jaman pemerintahan Raja Jayaśakti yang selain terdapat sinkretisme agama Budha dan Hindu juga terdapat aliran-aliran keagamaan seperti Waișrawa (Sumadio 1990: 432). Dari aspek perekonomian, prasasti-prasasti Danau Batur dapat mengungkapkan perdagangan masa lalu antara kawasan tersebut dengan wilayah-wilayah di luarnya. Diberitakan bahwa para penduduk di sekitar Danau Batur telah membudidayakan tanaman kapas yang hasilnya diperdagangkan sampai ke desa-desa di Bali Timur Laut, yakni ke desa Les, Paminggir, Bondalem, Julah, Purwasiddhi, Indrapura, Bulihan, dan Manasa (Goris 1974: 24). Di samping kapas, penduduk desadesa tepi Danau Batur juga telah mengusahakan perikanan. Bahkan, mereka juga mengenal peternakan kuda beserta usaha penyilangannya (Goris, 1974: 24 ). 
Salah satu berita yang menarik berasal dari Batur Pura Abang A. Penduduk di desa Abang mengajukan permohonan agar mereka mendapat tambahan tanah untuk kepentingan masyarakat karena mereka merasa bahwa desa kekurangan tanah untuk padang pengembalaan, pertanian, dan pencarian kayu bakar. Permohonan ini cukup beralasan, karena apabila dilihat kondisi geografis wilayah desa-desa sekitar Danau Batur, terutama bagian timur. Secara geografis wilayah tersebut berupa bukit-bukit terjal dan dataran sempit yang diapit pegunungan dan danau Batur, sehingga mereka hanya memiliki tanah yang sangat terbatas bagi pengusahaan mata pencaharian mereka. Permohonan tersebut dikabulkan oleh raja dan raja memberi sebagian tanah perburuan terdekat untuk penduduk desa Abang (Goris, 1974: 24).

Masih terdapat banyak sekali data historis dalam prasasti-prasasti kawasan Danau Batur yang dapat dieksplorasi dan diteliti lebih jauh lagi. Salah satu data historis yang menarik adalah tentang perpajakan dan aturan pewarisan yang dituliskan di dalam prasasti-prasasti tersebut. Aturan pewarisan yang didapatkan dalam prasasti Bali semacam itu sangat sedikit dimuat dalam prasasti-prasasti Jawa Kuno. Data historis tersebut akan sangat bermanfaat bagi interpretasi dan rekonstruksi sejarah sosial dan politik masa Indonesia kuno. Prasasti-prasasti yang ditemukan di Kawasan Danau Batur secara langsung membuktikan pula dominasi sosial dan politik kawasan tersebut pada masa sebelum ekspansi politik Majapahit ke Bali pada abad pertengahan 14 Masehi.

Dengan demikian, sebenarnya potensi data historis yang dapat diungkap oleh prasasti-prasasti Bali sangat besar. Uraian di atas adalah pemaparan sebagian kekayaan data historis yang dimiliki oleh prasasti Bali yang berasal dari prasasti yang sudah berhasil dibaca oleh para peneliti. Tentunya, kekayaan "harta karun" data historis tersebut akan semakin bertambah banyak apabila dapat dilakukan pembacaan dan penelitian terhadap prasasti-prasasti yang disimpan di beberapa pura di sekitar Danau Batur yang sampai saat ini belum diperbolehkan untuk dibaca.

\section{KETIKA PRASASTI KEHILANGAN MAKNA TEKSTUAL}

Berdasarkan pengamatan awal penulis dan beberapa peneliti epigrafi Bali diketahui bahwa telah tejadi pergeseran pemaknaan prasastiprasasti yang biasanya mereka simpan di dalam pura-pura mereka. M.M. Soekarto Kartoatmodjo, dkk. dalam sebuah laporan penelitian prasasti di Bali (1977: 2) mengemukakan:

"Penelitian Epigrafi di Bali lebih banyak dukanya daripada sukanya. Hal ini disebabkan karena prasasti khususnya dan benda-benda kuno umumnya, masih sangat disucikan dan dikeramatkan oleh masyarakat Bali. ... Kadang-kadang sebuah prasasti yang tersimpan dalam sebuah pura (temple) hanya dapat dibaca satu kali dalam 25 
tahun, bahkan ada yang tidak dapat dibaca untuk selama-lamanya, karena sangat dianggap keramat dan suci. Pembacaan prasasti yang dianggap keramat tersebut, menurut anggapan masyarakatnya akan berakibat mala petaka dan bahaya-bahaya lainnya."

Putu Budiastra (1977: 11) juga mengemukakan hal yang senada:

"Benda-benda kepurbakalaan di Bali [dalam hal ini prasasti (tambahan penulis)] sebagian besar masih berfungsi dan dikeramatkan oleh para penyungsungnya (penghormatnya). Mereka tidak akan tega andaikata benda-benda yang mereka simpan dan keramatkan dikeluarkan tidak pada waktunya. Mereka akan merasa cemas dan khawatir apabila benda tersebut diraba serta bergoreskan tangan orang lain tanpa seijin penyungsungnya."

Di samping beberapa pura mengijinkan pembacaan prasastinya, walaupun secara periodik, terdapat pula pura-pura yang sama sekali tidak mengijinkan pembacaan prasasti yang disimpan di dalam pura. Dengan demikian, terlihat bahwa pada saat ini telah terjadi pergeseran pemaknaan prasasti oleh para penyungsungnya di Bali. Dari sebuah piagam yang boleh dibaca oleh siapa saja pada masa lampau, menjadi sebuah relik keagamaan yang oleh umatnya dijadikan benda yang dikeramatkan pada masa kini. Pengkeramatan prasasti ini pada satu sisi akan mengubur data historis yang terkandung oleh prasasti-prasasti tersebut. Situasi tersebut dapat digambarkan dalam skema di bawah ini:

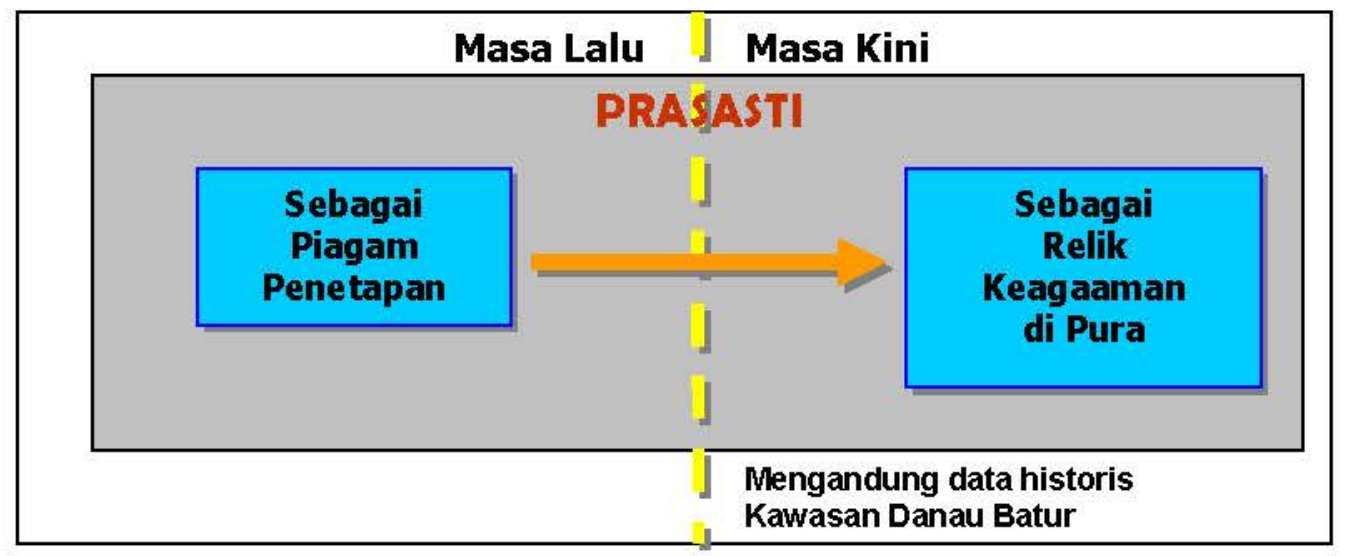

Pengalaman yang dituturkan oleh para peneliti prasasti di Bali menunjukkan bahwa prasasti sebagai relik keagamaan yang disimpan di dalam pura dianggap sangat suci atau dikeramatkan. Para penyungsung pura sangat yakin bahwa apabila prasasti tersebut dipegang atau dibaca oleh orang yang tidak berhak akan mendatangkan bencana bagi mereka. "Ketakutan" yang diwujudkan dalam keyakinan semacam itu sebenarnya terjadi di hampir semua pura, baik pura-pura yang sudah mengijinkan peneliti untuk membaca prasastinya dan lebih-lebih bagi pura yang sama sekali tidak mengijinkan orang untuk membaca prasastinya. 
Bagi pura yang mengijinkan pembacaan prasasti, ketakutan akan mendapatkan kutukan diatasi melalui cara penyelenggaraan upacara ritual pembacaan prasasti dan pemilihan waktu pembacaan yang telah diperhitungkan (berdasarkan perhitungan hari baik-buruk). Upacara ritual yang dilakukan pada waktu yang tepat akan dapat "menundukkan" kutukan yang ada. Dalam hal ini secara resiprokatif telah terjadi pertukaran kutukan dewa dengan upacara ritual yang dilaksanakan. Namun, dalam kasus pura yang tidak mengijinkan pembacaan prasasti, ketakutan akan kutukan dewa berada pada tingkat yang maksimal sehingga resiprokasitas upacara ritual tidak mampu lagi menandingi kutukan dewa yang diakibatkan oleh pelaksanaan pembacaan prasasti. Oleh karena itu, di beberapa pura muncul pelarangan sama sekali, atau kalau pun muncul niat untuk mengijinkan pembacaan, maka disyaratkan upacara ritual dengan biaya yang tidak masuk akal. Secara tidak langsung, syarat pelaksanaan upacara ritual yang sangat mahal tersebut pada dasamya adalah bentuk lain dari sebuah pelarangan atau penolakan.

Munculnya ketakutan terhadap kutukan dewa ini dipicu oleh persepsi yang salah terhadap sapatha atau kutukan yang dituliskan dalam prasasti. Biasanya pada beberapa prasasti dituliskan sumpah kutukan yang akan diterima oleh orang yang merusak dan mengubah isi prasasti. Dalam bagian akhir prasasti Terunyan disebutkan juga tentang kutukan semacam itu. Disebutkan bahwa orang yang merusak dan mengubah isi prasasti Terunyan akan mendapat kutukan Bhațāra (Budiastra 1990: 24). Kutukan dewa hanya ditujukan pada orang-orang yang merusak dan mengubah isi prasasti. Dalam prasasti-prasasti Bali Kuno (dan juga Jawa Kuno) tidak pernah disebutkan pelarangan pembacaan prasasti. Dengan demikian, jelaslah bahwa sebenamya kutukan itu sama sekali tidak ditujukan pada kegiatan pembacaan prasasti, tetapi banyak orang kemudian menafsirkan bahwa kutukan itu juga akan dapat terjadi pada orang-orang yang membaca prasasti.

Lebih jauh lagi, keberatan institusi pura (terutama para elit pendeta pura) terhadap pembacaan prasastinya dipicu oleh ketidaktahuan tentang isi sebenarnya prasasti-prasasti yang mereka simpan. Kebanyakan pemangku di pura-pura di Bali sudah tidak dapat lagi membaca dan mengerti isi prasasti-prasasti di puranya, karena prasasti-prasasti tersebut ditulis dengan aksara dan bahasa yang tidak lagi mereka pahami. Sangat sedikit pemangku pura di Bali yang mampu membaca aksara dan bahasa Jawa Kuno atau Bali Kuno. Menurut penuturan I Gusti Made Suarbawa, seorang peneliti prasasti Bali, di kawasan Danau Batur hanya terdapat seorang pemangku di Pejeng saja yang dapat membaca prasasti kuno.

Ketidakmampuan untuk mengetahui isi sebenarnya prasasti-prasasti yang mereka simpan dalam pura dapat berakibat pada dua hal yang kontradiktif. Pertama, beberapa pemangku justru menyadari ketidakmampuan dalam membaca prasasti dan kemudian memiliki keinginan untuk mengetahui isi prasasti yang mereka miliki. Pemangku yang memiliki kesadaran semacam itu kemudian biasanya akan 
mengundang peneliti prasasti untuk membantu membacakan prasasti. Kutipan di bawah ini ditulis oleh Putu Budiastra (1990) dalam laporannya yang menjelaskan bahwa kesadaran untuk mengetahui isi prasasti yang sebenarnya juga dimiliki oleh kelompok masyarakat di Kawasan Danau Batur:

"Laporan ini kami susun atas permintaan masyarakat desa Terunyan yang telah menyadari betapa pentingnya penyelamatan benda purbakala yang disimpan di desanya. Berdasarkan alasan di atas maka pada tanggal 6 Juli 1990 kami didatangai oleh Jero Kawidana yang juga menjabat sebagai Sekretaris Desa Terunyan. Jero Kawidana atas nama seluruh masyarakat desa Terunyan khususnya para penyungsung meminta kami agar kami membantu menyalin dan menterjemahkan (alih bahasa) isi prasasti yang mereka warisi dan keramatkan sampai sekarang."

Kedua, berbeda sangat kontras dengan kelompok yang pertama di atas, beberapa pemangku justru sangat bersikeras untuk tidak melakukan pembacaan prasasti milik pura mereka. Ketidakmampuan untuk membaca isi prasasti semakin mengubur keingintahuan mereka terhadap isi prasasti. Kelompok ini kemudian hanya memandang prasasti dari segi fisiknya saja, yaitu sebuah relik pura yang harus dikeramatkan.

Faktor lain yang semakin memperkuat keinginan untuk tidak memperbolehkan pembacaan prasasti adalah ketakutan terhadap isi prasasti itu sendiri. Pada dasarnya ketakutan tersebut adalah ketakutan terhadap dampak konflik yang dapat dipicu apabila isi prasasti diketahui oleh masyarakat umum. Prasasti sebagai sebuah piagam penetapan tentunya memuat ketetapan penguasa di masa lalu beserta dengan konsekuensi yang mengikutinya. Ketetapan-ketetapan prasasti di masa lalu masih dapat diberlakukan dalam kehidupan masyarakat saat ini di Bali.

Prasasti dapat menjadi sumber konflik apabila diketahui bahwa isi prasasti tersebut, yang berupa ketetapan-ketetapan penguasa pada masa lalu, bertentangan dengan keadaan saat ini. Kesenjangan perbedaan antara ketetapan di masa lalu dengan keadaan di masa kini dapat dimanfaatkan oleh kalangan tertentu di masyarakat untuk menggugat keadaan saat ini, demi kepentingan dan keuntungan kelompoknya sendiri. Hal ini akan menimbulkan konflik di dalam atau antar kelompok masyarakat di kawasan tersebut.

Di masa lalu pernah terjadi konflik antara Desa Terunyan dengan Desa Batur yang ditimbulkan oleh perbedaan pendapat tentang status desa mereka dikaitkan dengan isi sebuah prasasti. Danandjaja (1989: 50-51) menceritakan legenda perseteruan tersebut dalam disertasinya. Disebutkan bahwa orang Batur mengabarkan bahwa sebenarnya Desa Terunyan berada di bawah kekuasaan Desa Batur berdasarkan isi prasasti yang dimiliki oleh Desa Batur. Oleh karena orang Terunyan merasa sebaliknya, yaitu Desa Batur berada di bawah otoritas Desa Terunyan, maka pihak Desa Terunyan meminta bukti keberadaan prasasti terserbut. Namun, pihak 
Desa Batur tidak pernah dapat memenuhi permintaan tersebut. Oleh karena itu, kemudian orang-orang Terunyan menyatakan diri bahwa mereka justru memiliki kekuasaan atas Desa Batur berdasarkan sebuah prasasti yang sayangnya telah dihilangkan oleh seorang penduduk Desa Batur. Akibat kedua pihak tidak dapat menyajikan bukti prasasti yang dimaksud, maka perseteruan tersebut menjadi berlarut-larut. Pernah suatu ketika pemuka Desa Batur meminta orang desa Terunyan untuk menyumbangkan sesajian ke Pura Batur Ulun Danu pada setiap upacara piodalan (peringatan HUT pura), akan tetapi ditolak oleh orang Terunyan.

Terjadinya konflik antara Desa Batur dan Desa Terunyan tersebut memperlihatkan bahwa terdapat potensi konflik yang dapat diakibatkan oleh pembacaan sebuah prasasti, yang selanjutnya membuat beberapa kalangan masyarakat enggan membaca kembali prasastinya. Situasi demikian ini sangat berbeda dengan situasi di Jawa. Masyarakat Jawa menganggap bahwa prasasti adalah semata-mata sebuah artefak yang berasal dari masa lalu, sehingga ketetapan-ketetapan di dalamnya sudah tidak diberlakukan lagi pada masa kini.

Dari uraian di atas dapat disimpulkan bahwa pada beberapa pura di Kawasan Danau Batur telah terjadi pergeseran pemaknaan prasasti. Sebagai sebuah piagam penetapan seharusnya prasasti boleh dibaca untuk diketahui isinya. Akan tetapi justru saat ini mereka tidak mengijinkan hal tersebut terjadi, karena mereka memandang prasasti sebagai benda keramat yang sangat disucikan, dan tidak boleh disentuh oleh orang kecuali para pemangkunya.

Pergeseran pemaknaan prasasti diperkirakan terjadi bersamaan dengan proses menipisnya kemampuan para elit keagamaan dalam bidang penguasaan bahasa dan aksara kuno yang digunakan dalam prasasti (bandingkan dengan Fox 2003). Seperti telah dikemukakan pada bagian yang terdahulu bahwa pada saat ini hampir tidak ada lagi pendeta pura yang menguasai bahasa kuno prasasti. Ketika para pendeta pura tidak lagi menguasai bahasa dan aksara kuno prasasti, maka secara berangsurangsur lenyaplah pula pemahaman terhadap isi prasasti. Pada saat para pendeta, lebih-lebih para umatnya, sudah tidak dapat mengetahui lagi isi prasasti, pemaknaan prasasti sebagai sebuah piagam penetapan pun ikut sima. Oleh karena prasasti-prasasti tersebut sudah sedemikian lama disimpan di pura, maka kemudian yang terjadi adalah prasasti dimaknai sebagai benda atau relik keagaamaan seperti pratima-pratima (bendabenda suci) lain yang disimpan di pura. Proses pergeseran pemaknaan prasasti tersebut tentunya terjadi dalam kurun waktu yang lama, paling tidak dimulai sejak berlangsungnya perubahan bahasa dan aksara Jawa kuno serta Bali kuno menjadi Jawa dan Bali modem. 
Sebuah Refleksi:

Haruskah Perubahan Tersebut Disesali?

Things play an active role within our society, just like human beings.

(Jody Joy 2004)

Bagi seorang peneliti epigrafi (prasasti) perubahan paradigma prasasti oleh masyarakat dari 'tekstual' menjadi 'non-tekstual' sangat merugikan. Ketika masyarakat pemiliknya sudah tidak memandangkan prasasti sebagai sebuah piagam lagi tetapi sebagai sebuah relik keagamaan yang dikeramatkan, maka seketika itu juga dia kehilangan data historis yang tak terkira nilainya. Dari perspektif peneliti, kehilangan data historis tersebut dianggap merugikan masyarakat pemilik prasasti itu sendiri, karena si pemilik pun seolah-olah menguburkan masa lalunya, jati dirinya sendiri. Bagi masyarakat penyungsung pura di kawasan Danau Batur pergeseran pemaknaan prasasti tersebut tidak dianggap sebagai hal yang penting dalam kehidupan sehari-hari mereka. Masyarakat saat ini memandang bahwa prasasti merupakan salah satu pratima penting dalam pura mereka. Prasasti lebih dipandang sebagai legalitas sejarah pura mereka, walaupun sebenamya mereka tidak tahu persis tuturan sejarah yang termuat dalam prasasti tersebut. Namun demikian, ada pula anggota masyarakat yang mulai berusaha untuk mengetahui isi prasasti-prasasti yang dimiliki oleh pura mereka. Salah satu dari mereka adalah para pengurus pura Terunyan yang memanggil peneliti prasasti untuk membacakan prasasti mereka. Demikian pula Wayan Wates, seorang guru SD Terunyan yang ingin mengetahui isi prasasti Terunyan agar dapat disampaikan kepada murid-muridnya.

Pada dasamya, proses perubahan pemaknaan tersebut terjadi dalam masyarakat kawasan Danau Batur secara alamiah dan dalam kurun waktu yang panjang. Perubahan tersebut merupakan sebuah proses budaya yang terjalin dari jejaring budaya yang tumbuh dan berkembang dalam masyarakat itu sendiri. Oleh karena itu, tidaklah bijaksana apabila sebuah intervensi eksternal dipaksakan terhadapnya untuk kembali memaknai prasastinya sebagai sebuah prasasti seperti dahulu kala. Pemaksaan intervensi ekstemal yang tiba-tiba akan meminta korban sosial budaya yang cukup besar. Dalam pendekatan Cultural Resources Management atau pengelolaan sumberdaya arkeologi yang berkembang belakangan ini, ditekankan adanya kesadaran baru untuk lebih memperhatikan pemaknaan sosial terhadap peninggalan budaya masa lalu. Oleh karena itu dalam pengelolaannya pun harus memperhatikan kehidupan sosial budaya lokal pada saat ini (Byrne, t.t.).

Apabila para peneliti masih tetap ingin menggali "harta karun" data historis yang dimiliki prasasti-prasasti tersebut, maka harus dilakukan secara bijaksana. Jalan terbaik yang dapat dilakukan adalah dengan cara memberikan pemahaman secara perlahan dan bertahap kepada segenap 
penyungsung pura tentang pentingnya data historis yang dimiliki prasastiprasasti yang mereka simpan di dalam puranya.

Yumu Pakatahu.

\section{KEPUSTAKAAN}

Ayatrohaedi. 1981. Kamus /stilah Arkeologi.Jakarta: Pusat Pembinaan dan Pengembangan Bahasa, Departemen Pendidikan dan Kebudayaan.

Bakker, JMW. 1972. IImu Prasasti Indonesia. Djurusan Sedjarah Budaja IKIP Sanata Dharma, Jogjakarta.

Boechari, "Epigrafi dan Sejarah Indonesia", Majalah Arkeologi, Th.I.,No. 2. 1977.

Budiastra, Drs. Putu dan Drs. Wayan Wardha. 1990. Prasasti Desa Terunyan Kintamani. Museum Bali Direktorat Permuseuman Direktorat Jendral Kebudayaan Departemen Pendidikan dan Kebudayaan.

Budiastra, Putu. 1977. Empat Lembar Prasasti Raja Jayapangus. Proyek Pengembangan Media Kebudayaan Ditjen Kebudayaan Departemen Pendidikan dan Kebudayaan R.I.

Byme, Denis et al. t.t. Social Significance. A discussion Paper. Hurstville: Research Unit, Cultural Heritage Divison, NSW National Parks and Wildlife Service.

Danandjaja, James, Dr. 1989. Kebudayaan Petani Desa Terunyan di Bali. Jakarta: Penerbit Universitas Indonesia.

Fox, Richard. "Substantial Transmissions; A Presuppositional Analysis of the Old Javanese Text as an Object of Knowledge, and its Implications for the Study of Religion in Bali", In: Bijdragen tot de Taal-, Land- en Volkenkunde 159 (2003), no: 1, Leiden, 65-107

Goris, R. 1936. Sejarah Bali Kuno. Denpasar: Percetakan Bali.

Goris, Roelof. 1954. Prasasti Bali I dan Prasasti Bali II. Jakarta: Lembaga Bahasa dan Budaya, Universitet Indonesia.

1974. Beberapa Data Sejarah dan Sosiologi dari Piagampiagam Bali. Bhratara, Jakarta. 
Joy, Jody. 2004. Biography of a medal: people and the things they value.

Dalam: John Schofield, William Gray Johnson and Colleen M. Beck (eds.). Matériel Culture The Archaeology of Twentieth-Century Conflict. New York: Routledge.

Kartoatmodjo, Drs. M.M. Soekarto, et al. 1977. "Laporan Penelitian Epigrafi Bali Tahap I". Berita Penelitian Arkeologi No. 11. Proyek

Pengembangan Media Kebudayaan Departemen P dan K, Jakarta.

Ottino, Arlette. 1994. "Origin Myths, Hierarchical Order, and the Negotiation of Status in the Balinese village of Trunyan". In: Bijdragen tot de Taal-, Land-en Volkenkunde 150 (1994), no: 3, Leiden, 481-517.

Prasodjo, Tjahjono. 1998. "Epigrafi Indonesia: Peran, Kedudukan, dan Pengembangannya, Berkala Arkeologi, Th. XVIII. Edisi Khusus.

Reuter, Thomas, 2002. "The House of Our Ancestors", Verhandilingen van het Koninklijk Instituut voor Taal-, Land- en Volkenkunde. Leiden: KITLV Press.

2005. Custodians of the Sacred Mountains: Budaya dan Masyarakat di Pegunungan Bali. Jakarta: Yayasan Obor Indonesia.

Sumadio, Bambang, ed., 1990. Sejarah Nasional Indonesia II. Balai Pustaka, Jakarta.

Suarbhawa, I Gusti Made. 2005. "Permukiman di daerah Pegunungan Kintamani Selatan dan Barat, Eksplorasi Sumber Data Tertulis". Dalam: I Made Sutaba, ed. Khasanah Arkeologi: Pemanfaatan Sumberdaya Arkeologi. Ikatan Ahli Arkeologi Indoensia Komda Bali dan Balai Arkeologi Denpasar.

van Stein Callenfels, P.V. 1926. "Epigraphia Balica I", V.B.G. LXVI. G. Kolff \& Co.

\section{Ucapan Terimakasih}

Penulis mengucapkan terimakasih kepada segenap pengelola Program Beastudi Kajian Antarbudaya/Antarregional, Pusat Studi Asia Pasifik, Universitas Gadjah Mada pada tahun 2005/2006 atas kesempatan yang telah diberikan untuk melakukan penelitian di Terunyan, Bali. Demikian pula diucapkan terimakasih sebesar-besarnya kepada Prof. Dr. Sumijati Atmosudiro yang telah mendorong, memberi semangat, dan masukan dalam penelitian ini. Akhirnya, terima kasih kepada Wicaksono Dwi Nugroho, S.S., M.Hum. yang telah menjadi teman diskusi dan mitra peneliti selama di lapangan. 